\title{
Immunoglobulin lambda light chain genes in rheumatoid arthritis
}

\author{
DAVID SIDEBOTTOM, ' DAVID M GRENNAN, ${ }^{\prime}$ PAUL A SANDERS, ${ }^{\prime}$ AND \\ ANDREW READ ${ }^{2}$ \\ From the 'University of Manchester Rheumatic Diseases Centre, Hope Hospital, Salford; and the 2University \\ Department of Medical Genetics, St Mary's Hospital, Manchester
}

SUMMARY Restriction fragment length polymorphisms (RFLPs) obtained by hybridisation of an immunoglobulin $\lambda$ constant region probe to Eco RI digests of genomic deoxyribonucleic acid (DNA) obtained from rheumatoid arthritis (RA) and control subjects have been compared. Polymorphic bands of $8,13,18$, and $23 \mathrm{~kb}$ (kilobases) were shown. The $8 / 8$ genotype and $8 \mathrm{~kb}$ allele were increased and the $8 / 18$ genotype and $18 \mathrm{~kb}$ allele decreased in the RA group. This effect was independent of HLA and Gm. These findings suggest that genes linked to the loci for the immunoglobulin $\lambda$ constant region may influence susceptibility to RA.

Key words: immunogenetics, RFLPs, genetic predisposition.

Rheumatoid arthritis (RA) results from an interaction between an oligogenic susceptibility and unknown environmental factors. ${ }^{1}$ Part of this genetic susceptibility is accounted for by genes within the major histocompatibility complex (MHC). An estimate of the proportion of the total genetic predisposition to RA contributed by genes within the MHC can be calculated from knowledge of the concordance rates in monozygotic and dizygotic twins and the relative frequencies with which affected sibling pairs share both or no haplotypes. $^{2}$ When concordance ${ }^{1}$ and haplotype sharing figures ${ }^{3}$ currently available are used the genes linked to HLA can be estimated to contribute less than $50 \%$ of the total genetic contribution to RA and possibly as little as $20-30 \%$. Other potential candidates as susceptibility genes for RA include genes coding for immunoglobulin heavy chains and $x$ and $\lambda$ light chains on chromosomes 14,2 , and 22 respectively. Previous studies have shown a population association between RA and particular allotypes of the immunoglobulin heavy chain marker, Gm. ${ }^{45}$ This effect appears relatively weak, however, probably dependent on an interaction with genes within the MHC, and still leaves a considerable proportion of the total genetic predisposition to RA unaccounted for. Clinical investigation of the

Accepted for publication 17 March 1987.

Correspondence to Dr David M Grennan. Rheumatic Discases Centre. Hope Hospital. Salford M6 8HD. UK. immunoglobulin light chain loci has been difficult in the past as there are no allotypic $\lambda$ markers and polymorphism of $\mathrm{Km}$, an allotype on the constant region of the $x$ light chain, is limited. Even with the limited $x$ polymorphism, involvement of genes linked to the $x$ light chain loci has been suggested by population associations found between $\mathrm{Km}_{1}$, and immunological response to bacterial antigens ${ }^{6}$ as well as associations between $\mathrm{Km}_{1}$ and SSB autoantibody formation in patients with connective tissue disease. ${ }^{7}$ Possible involvement of immunoglobulin light chain genes in susceptibility to disease may now be investigated by the use of appropriate immunoglobulin light chain DNA probes. In the present study, by comparing restriction fragment length polymorphisms (RFLPs) obtained by hybridisation of an immunoglobulin $\lambda$ constant region probe ${ }^{\gamma}$ to restriction endonuclease digests of genomic DNA obtained from RA and control subjects, we have looked for evidence that genes linked to the immunoglobulin $\lambda$ constant or junctional $(\mathrm{J})$ region loci on chromosome 22 may influence susceptibility to RA.

\section{Patients and methods}

PATIENTS

One hundred and eight unrelated patients with classical or definite $\mathrm{RA}^{\mathrm{y}}$ and 104 unrelated controls 


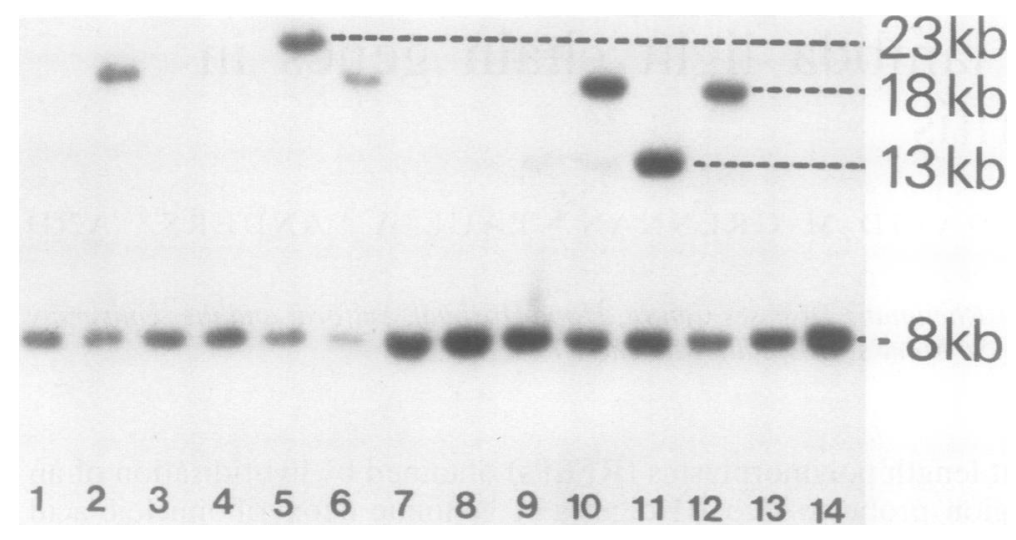

Fig. 1 Autoradiograph showing $8 k b, 13 k b, 18 k b$, and $23 k b$ bands obtained with the immunoglobulin $C \lambda$ probe. Thus lanes $1,3,4,7,8,9,13$, and 14 are $8 / 8$ homozvgotes, lane 11 an $8 / 1.3$ heterozvgote, lanes $2,6,10$. and 12 are $8 / 18$ heterozygotes, and lane 5 an $8 / 23$ heterozygote. In some of the strongly hybridising lanes, weak non-polymorphic bands at $14 \mathrm{~kb}$ and $16 \mathrm{~kb}$ are seen which may be disregarded. These represent partial homology between the probe used and adjoining Eco RI fragments flanking the central polymorphic sequence within the $C \lambda$ region. were studied. Both patients and controls were Caucasians living in north west England.

L. A B OR A TORY

DNA was extracted from circulating white cells." After digestion with Eco RI, fragments were separated by agarose gel electrophoresis and transferred to nitrocellulose or nylon (Hybond $\mathrm{N}$ ) filters." An immunoglobulin $C \dot{\lambda}$ probe was kindly donated by Professor Leder and has previously been shown to demonstrate polymorphism in the $\lambda$ constant region. ${ }^{12}$ This polymorphism depends on insertion of additional base sequences between Eco $\mathrm{RI}$ restriction sites. A 5th $\mathrm{Bam} \mathrm{Hl}$ fragment from plasmid P1A5 was used which contains flanking $\mathrm{J}$ region sequences. The probe was radiolabelled by oligonucleotide-primed synthesis ${ }^{1,3}$ and hybridised under conditions previously described ${ }^{12}$ to the filters to show polymorphic bands of 8.13 .18 . and 23 kilobases (kb) (Fig. 1).

\section{Results}

The restriction fragment genotype frequencies in RA and control group are shown in Table 1. The overall distributions of genotype frequencies in RA and control groups were different. and there was a significant increase in the $8 / 8$ genotype frequency and decrease in the $8 / 18$ genotype frequency in the RA group (the latter $p$ values are uncorrected for the number of comparisons made). Genotype frequencies were similar in DR4 positive and negative RA groups, and there was no evidence of an interaction between immunoglobulin $\lambda$ variants and $\mathrm{Gm}$.
Table 1 Human ( i. immunoglobulin locus RFLP genotype frequencies in $R A$ and control groups (non-RA

\begin{tabular}{|c|c|c|c|c|c|c|}
\hline \multirow[t]{2}{*}{ Groulp } & \multicolumn{3}{|c|}{ (i'nolype } & \multirow{2}{*}{823} & \multirow[b]{2}{*}{$J S I S$} & \multirow[b]{2}{*}{1318} \\
\hline & $8 s$ & 813 & $8 / 8$ & & & \\
\hline $\begin{array}{l}\text { Controls } \\
(n=1() 4) \\
\operatorname{RA}^{(n=1() 8)}\end{array}$ & $\begin{array}{l}70 \\
9(1)\end{array}$ & $\begin{array}{l}4 \\
4\end{array}$ & $\frac{25 \%}{14 \%}$ & i) & $\begin{array}{l}1 \\
0\end{array}$ & 1 \\
\hline
\end{tabular}

$\chi^{2}=7 \cdot 350: p<0 \cdot 01$

$\div \chi^{2}=4 \cdot 329: p<0 \cdot 05$

Overall $\chi^{2}$ comparing $8 / 8,8 / 13,8 / 18$, and other genotvpes in RA and control groups: $\chi^{2}=10.531: \mathrm{p}<0.025$.

Table 2 Allele frequencies in RA and control groups

\begin{tabular}{|c|c|c|c|c|}
\hline \multirow[t]{2}{*}{ (irolup } & \multicolumn{2}{|l|}{ Allele } & \multirow[b]{2}{*}{$1 s k h$} & \multirow[b]{2}{*}{23} \\
\hline & $s k b$ & $13 \mathrm{~kb}$ & & \\
\hline $\begin{array}{l}\text { Controls } \\
(n=1(1) 4)\end{array}$ & 172 & 5 & 28 & 3 \\
\hline $\mathrm{RA}^{\prime}(\mathrm{n}=1(1))$ & $19 \bar{s}$ & 4 & $14 \%$ & 11 \\
\hline
\end{tabular}

Overall $\chi^{2}$ comparing $8,13,18$, and $23 \mathrm{~kb}$ alleles in RA and contro groups: $\chi^{2}=9.457: p<0.125$.

Gene frequencies are shown in Table 2. Thereळ was a significant increase of the $8 \mathrm{~kb}$ allele (themost striking effect statistically) and a decrease of $\frac{0}{0}$ the $18 \mathrm{~kb}$ allele in the RA group (the latter $\mathrm{p}$ value loses statistical significance if corrected for the $\frac{\mathscr{Q}}{\mathbb{Q}}$ number of alleles). Observed genotype frequenciese in both RA and control groups were similar to 
Table 3 Comparison of observed genotype frequencies with expected frequencies (calculated from the Hardy-Weinberg law)

\begin{tabular}{llllllll}
\hline Group & \multicolumn{3}{l}{ Genotype } \\
\cline { 2 - 7 } & $8 / 8$ & $8 / 13$ & $8 / 18$ & $8 / 23$ & $18 / 18$ & $13 / 18$ \\
\hline $\begin{array}{l}\text { Controls } \\
\text { Obs. }\end{array}$ & 0.673 & 0.038 & 0.240 & 0.029 & $0.0(1)$ & 0.009 \\
Exp. & 0.684 & 0.040 & 0.223 & 0.023 & 0.018 & 0.006 \\
RA & & & & & & \\
Obs. & 0.833 & 0.037 & 0.130 & 0 & 0 & 0 \\
Exp. & 0.841 & $0 .(035$ & 0.119 & 0 & $0 .(1) 4$ & 0.002 \\
\hline
\end{tabular}

values calculated from gene frequencies using the Hardy-Weinberg formula (Table 3).

\section{Discussion}

These studies have shown a significant association between a restriction fragment obtained with an immunoglobulin $\lambda$ light chain DNA probe and rheumatoid arthritis. The probe contains $J$ flanking region as well as constant region sequences. The association appears weak (the relative risk is only increased twofold) and conceivably could be due to chance. The effect is independent of DR and Gm, and one possible explanation of these findings is that immunoglobulin $\lambda$ constant or $\mathrm{J}$ region genes themselves might influence susceptibility towards rheumatoid arthritis. The polymorphism demonstrated with the $C \lambda$ probe depends on insertion of additional base sequences between Eco RI restriction sites. Thus the $8 \mathrm{~kb}$ fragment contains two $C \lambda$ genes, the $13 \mathrm{~kb}$ fragment contains three, the $18 \mathrm{~kb}$ fragment contains four, and the $23 \mathrm{~kb}$ fragment five. ${ }^{12}$ Hence the association between RA and the 8 $\mathrm{kb}$ fragment might conceivably reflect loss of protective or control genes in the immunoglobulin $\lambda$ constant or $\mathbf{J}$ regions, although it is uncertain how many of these duplicated genes are active and in any case no immunological function has been assigned to the $\lambda$ constant region.

An alternative and more likely explanation for the association is that this is due to linkage disequilibrium between the $8 \mathrm{~kb}$ fragment and a gene at a nearby locus, such as a $\lambda$ variable region gene. Adams and coworkers have proposed a scheme for involvement of immunoglobulin light chain $\mathrm{V}$ genes in the pathogenesis of other autoimmune disorders. ${ }^{14}$ This group has also shown that pathogenic autoantibodies to thyroid tissue are more likely to arise from immunoglobulin $\lambda$ than $x$ clones. ${ }^{15}$ Our findings could represent an effect of particular immuno- globulin light chain $\mathrm{V}$ genes increasing susceptibility to rheumatoid arthritis. A polymorphic immunoglobulin $\mathrm{V} \lambda$ DNA probe is available, and further studies with this probe would be of interest. ${ }^{16}$

These studies were supported by a research grant from the Nuffield Foundation. We are grateful to Professor Leder and his colleagues for providing the immunoglobulin $C \lambda$. probe. The HLA typing was by courtesy of Dr P A Dyer.

\section{References}

1 Lawrence J S. Rheumatoid arthritis. Rheumatism in populations. London: Heinemann. 1977: 156-271.

2 Grennan D M. Sanders P A. Dyer P A. Harris R. HLA haplotype sharing by siblings with rheumatoid arthritis: evidence for genetic heterogeneity. Ann Rheum Dis 1986; 45: 126-9.

3 Rotter J I. Landaw E M. Measuring the genetic contribution of a single locus to a multilocus disease. Clin Genet 1984: 26: $259-62$.

4 Sanders P A, de Lange G G, Dyer P A, Grennan D M. Gm and $\mathrm{Km}$ allotypes in rheumatoid arthritis. Ann Rheum Dis 1985; 44: 529-32.

5 Propert D N, Kay P. McCluskey J, Zilko P J, Mathews H. Immunoglobulin allotypes in rheumatoid arthritis. In: Dawkins R L. Christiansen F T, Zilko P J, eds. Immunogenetics of rheumatoid arthritis. Amsterdam: Excerpta Medica, 1982: 122-9.

6 Pandey J P. Virella G. Loadholt C B. Fudenberg H H. Kyong C U. Galbraith R M. Association between immunoglobulin allotypes and immune response to Hacmophilus influenzac and meningococcus polysaccharides. Lancet 1979: i: 190-2.

7 Whittingham S. Propert D N. MacKay C R. A strong association between the antinuclear antibody anti-La (SSB) and the kappa light chain allotype $\mathrm{Km}_{1}$. Immunogenetics 1984: 19: 245-99.

8 Heiter P A. Hollis G F. Korsmeyer S J. Waldmann T A. Leder P. Clustered arrangement of immunoglobulin constant region genes in man. Nature 1981: 294: 536-40.

9 Ropes M W. Diagnostic criteria for rheumatoid arthritis: 1958 revision. Ann Rheum Dis 1959; 18: 49-53.

10 Kunkel L M. Smith K D. Boyer S H. et al. Analysis of human Y-chromosome specific reitcrated DNA in chromosome variants. Proc Natl Acad Sci USA 1977: 74: 1245-9.

11 Maniatis T. Fritsch E F. Sambrook J. Molecular cloning: a laboratory manual. New York: Cold Spring Harbor Laboratory. 1982: 383-9.

12 Taub R A. Hollis G F. Hicter R A. Korsmeyer S. Waldmann T A. Leder P. Variable amplification of immunoglobulin lambda light-chain genes in human populations. Nature 1983: 304: $172-4$.

13 Feinberg A P. Vogelstein B. A technique for radiolabelling DNA restriction endonuclease fragments to high specific activity. Anal Biochem 1983; 132: 6-13.

14 Adams D D. Knight J G. White P. et al. A solution to the genetic and environmental puzzles of insulin-dependent diabetes mellitus. Lancet 1984; i: $42(1)-4$.

15 Knight J. Laing P. Knight A. Adams D. Ling N. Thyroidstimulating autoantibodics usually contain only $\lambda$-light chains: evidence for the 'forbidden clone' theory. J Clin Endocrinol Metab 1986: 62: 342-7.

16 Anderson M L M. Szajnert M F. Kaplan J C. McColl L. Young $B$. The isolation of a human Ig $V$ lambda gene from a recombinant library of chromosome 22 and estimation of its copy number. Nucleic Acids Res 1984; 12: 6647-61. 